\title{
Intelligent Scroll Order Generator Software from View Movements in People with Disabilities
}

\author{
Juan Ríos-Kavadoy ${ }^{1}$, Harold Guerrero-Bello², Michael Cabanillas-Carbonell ${ }^{3}$ \\ Facultad de Ingeniería \\ Universidad Privada del Norte \\ Lima, Perú
}

\begin{abstract}
People with motor disabilities face problems such as being able to move around independently, as well as having difficulties to take advantage of the technological tools developed for their rehabilitation. This research is based on computer vision and robotics, and was carried out with the objective of generating displacement orders using smoothed and binarized algorithms to assist the displacement of disabled people. The intelligent software for people with disabilities or motor deficiencies generates movement commands for an acceptable time through visual commands made by the person, by means of communication between the camera and the software, constantly capturing images. The results obtained for the scene (image) is cropped according to the face scene, then the view scene is cropped according to the face scene, and by means of necessary algorithms the pupil must be found; The complexity lies not only in locating the pupil, but also in identifying when a command is being sent and when it is not. Finally, the unit processes the movement command (left and right) to turn the LEDs on and off.
\end{abstract}

Keywords-Displacement; motor disability; pupil; computer vision of images

\section{INTRODUCTION}

According to the UN and WHO [1]-[3], around the world, more than 1 billion people have disabilities, about $15 \%$ of the world's population, of whom more than 200 million suffer from motor difficulties, being $3.8 \%$ considered to be severely disabled. According to Hawking [3], who has suffered from motor neuropathy since adulthood, he states that this motor disability has not been an obstacle to achieve his goals, being technology his support to lead a normal life.

In Peru [4], there are different types of diseases that prevent people with disabilities from carrying out their activities normally, representing $59.2 \%$ of the total population with disabilities, preventing them from moving from one place to another, climbing stairs, going down stairs, etc. In everyday life, orders or actions are performed by different means, such as voice, for example, to activate the cell phone, open/close the door of the house, etc., and all that the world of home automation has to offer. But little in eye tracking is to give the same orders as voice, hand, etc.

Motor difficulty (movements in the hands, feet, etc.) also called as coordination disorder which prevents the generation of movement commands to the body due to chronic neurological impairment [5], [6]. There are different options to be able to capture the brain's orders, one of which is by means of nerve impulses, brain waves where physiological orders can be carried out by means of these [7], [8], another option is to use eye movements by means of visual perception.

The interaction between the brain and the computer allows the patient with motor disabilities to increase their cognitive abilities and self-sufficiency; however, accuracy problems are often encountered [7]. To solve these problems we propose the use of eye movements translated by the computer into physiological movements by training algorithms for greater accuracy and for the efficient operation of external devices such as wheelchairs.

Taking the last mentioned, the present project is intended to cover 02 areas of Artificial Intelligence (digital image processing [9] and robotics [10]), two problems were encountered to carry out the orders by means of the view, the first one is to be able to discriminate the orders of those that are not, considering that at a certain moment it can be visualizing a landscape, but not generating an order, therefore it is desired to find the recognition of orders, and second problem encountered is that the orders of displacement carried out are correct, carrying out the action in the indicated direction.

As a background to the study, the following studies have been considered, an important contribution presented in Panama, is the SOLCA software [11], which supports people with disabilities in the use of hands, for this purpose is agency of sight to be able to manipulate a computer. Another relevant contribution presented in USA [12], is the design of a virtual environment used as a simulator contributing to be a support tool in the rehabilitation of people with some degree of motor disability, based on virtual reality. It was obtained that increased confidence in patients.

In research [13], a drawing interface for human-computer interaction was realized where image processing was used, interface control was developed by tracking the patient's nose. As a result, it was found that young patients found the system easy to use, but in adult patients there was a lack of familiarity with the software.

Although there have been several previous investigations on the case, carried out with a variety of methods with the aim of helping the patient in his rehabilitation, it has been identified that most of the patients show some difficulty in adaptation, this is due to the lack of familiarity of the patient, to the unfriendly environments of the interfaces that cause the disabled person to make some physical effort. 
The present research aims to provide a trained algorithm from which a digital image processing was performed, typical of artificial intelligence, where information has to be extracted from a scene, in order to be implemented in the future to a wheelchair. It also has an applicative justification since it works with hardware that is used for people with motor disabilities, as valuation we have that it can be scalable and can be used by a greater number of people and also has a social justification, since this research is born from a problematic reality for the support of people with motor deficiency providing a non-invasive and easy to use support for the patient.

\section{Methodology}

The main functions to be performed are to locate the eyes and analyze the position of the pupil within the central position of the eye by listening to the left (i) and right (d) commands, to subsequently switch on the LED defined for the left and right position and start processing the scene and improving the captured image, finally identifying the commands.

The research conducted is of a pre-experimental type, which allows to optimally administer the treatment to a group [14], applying a stimulus (intelligent software) for the resolution of the problem.

\section{A. Population and Sample (Materials, Instruments and Methods)}

The population is made up of 100 realized visual orders, as trials the orders are left and right. Therefore, the object of study is given by the visual orders. To obtain these visual orders, 5 attempts of order of each side are considered, performed to 10 persons, therefore 10 attempts $\times 2$ sides $\mathrm{x} 10$ persons, in total 200 orders of displacement, which will be submitted to evaluation of the certainty.

\section{B. Techniques and Instruments for Data Collection and Analysis}

\section{1) Data collection}

a) Transfer technique: It consists of recording the data that are obtained in the instruments called files, which are duly prepared and organized and contain most of the information collected in a research, and therefore constitute a valuable auxiliary instrument in this task [15].

b) Record card: Evaluation card of visual displacement orders generated and evaluated according to their result.

c) Validity: The degree to which an instrument actually measures the variable it intends to measure.

d) Data analysis: Applied research refers to scientific study that seeks to solve practical problems [16]. It is used to find solutions to everyday problems, cure diseases and develop innovative technologies.

\section{Procedure}

For the present investigation, two techniques will be taken into account: Observation and Record Card, considered for the acquisition of data, as shown in the data table, where the data obtained from the attempts to generate visual orders are observed, identifying which of them have really been visual orders.

\section{1) Data Collection Before using the Intelligent Software}

a) Indicador 1: Rate of recognition of travel orders. Data collection before using smart software for the travel order recognition rate indicator (see Table I). Correctly Generated Visual Commands (CGCOs).

b) Indicator 2: Orders performed correctly. Data collection before using smart software for indicator correct orders made (see Table II).

table I. Pre-Test Data of the Travel Order Recognition IndeX INDICATOR

\begin{tabular}{|c|c|c|c|c|c|}
\hline $\begin{array}{l}\text { Test } \\
\text { case }\end{array}$ & Attempts & $\begin{array}{l}\text { Total } \\
\text { Attempts }\end{array}$ & CGCO & $\begin{array}{l}\text { Recognition } \\
\text { Rate }\end{array}$ & $\begin{array}{l}\text { Recognition } \\
\text { Rate (\%) }\end{array}$ \\
\hline \multirow{2}{*}{$\begin{array}{l}\text { Person } \\
1\end{array}$} & $\begin{array}{l}\text { Attempts } \\
\text { left }\end{array}$ & 10 & 6 & 0.60 & $60 \%$ \\
\hline & $\begin{array}{l}\text { Attempts } \\
\text { right }\end{array}$ & 10 & 4 & 0.40 & $40 \%$ \\
\hline \multirow{2}{*}{$\begin{array}{l}\text { Person } \\
2\end{array}$} & $\begin{array}{l}\text { Attempts } \\
\text { left }\end{array}$ & 10 & 6 & 0.60 & $60 \%$ \\
\hline & $\begin{array}{l}\text { Attempts } \\
\text { right }\end{array}$ & 10 & 7 & 0.70 & $70 \%$ \\
\hline \multirow{2}{*}{$\begin{array}{l}\text { Person } \\
3\end{array}$} & $\begin{array}{l}\text { Attempts } \\
\text { left }\end{array}$ & 10 & 6 & 0.60 & $60 \%$ \\
\hline & $\begin{array}{l}\text { Attempts } \\
\text { right }\end{array}$ & 10 & 4 & 0.40 & $40 \%$ \\
\hline \multirow{2}{*}{$\begin{array}{l}\text { Person } \\
4\end{array}$} & $\begin{array}{l}\text { Attempts } \\
\text { left }\end{array}$ & 10 & 7 & 0.70 & $70 \%$ \\
\hline & $\begin{array}{l}\text { Attempts } \\
\text { right }\end{array}$ & 10 & 7 & 0.70 & $70 \%$ \\
\hline \multirow{2}{*}{$\begin{array}{l}\text { Person } \\
5\end{array}$} & $\begin{array}{l}\text { Attempts } \\
\text { left }\end{array}$ & 10 & 8 & 0.80 & $80 \%$ \\
\hline & $\begin{array}{l}\text { Attempts } \\
\text { right }\end{array}$ & 10 & 6 & 0.60 & $60 \%$ \\
\hline \multirow{2}{*}{$\begin{array}{l}\text { Person } \\
6\end{array}$} & $\begin{array}{l}\text { Attempts } \\
\text { left }\end{array}$ & 10 & 7 & 0.70 & $70 \%$ \\
\hline & $\begin{array}{l}\text { Attempts } \\
\text { right }\end{array}$ & 10 & 4 & 0.40 & $40 \%$ \\
\hline \multirow{2}{*}{$\begin{array}{l}\text { Person } \\
7\end{array}$} & $\begin{array}{l}\text { Attempts } \\
\text { left }\end{array}$ & 10 & 7 & 0.70 & $70 \%$ \\
\hline & $\begin{array}{l}\text { Attempts } \\
\text { right }\end{array}$ & 10 & 4 & 0.40 & $40 \%$ \\
\hline \multirow{2}{*}{$\begin{array}{l}\text { Person } \\
8\end{array}$} & $\begin{array}{l}\text { Attempts } \\
\text { left }\end{array}$ & 10 & 7 & 0.70 & $70 \%$ \\
\hline & $\begin{array}{l}\text { Attempts } \\
\text { right }\end{array}$ & 10 & 8 & 0.85 & $85 \%$ \\
\hline \multirow{2}{*}{$\begin{array}{l}\text { Person } \\
9\end{array}$} & $\begin{array}{l}\text { Attempts } \\
\text { left }\end{array}$ & 10 & 8 & 0.80 & $80 \%$ \\
\hline & $\begin{array}{l}\text { Attempts } \\
\text { right }\end{array}$ & 10 & 4 & 0.40 & $40 \%$ \\
\hline \multirow{2}{*}{$\begin{array}{l}\text { Person } \\
10\end{array}$} & $\begin{array}{l}\text { Attempts } \\
\text { left }\end{array}$ & 10 & 4 & 0.40 & $40 \%$ \\
\hline & $\begin{array}{l}\text { Attempts } \\
\text { right }\end{array}$ & 10 & 6 & 0.60 & $60 \%$ \\
\hline \multicolumn{2}{|c|}{ TOTAL(TO) } & 200 & 48 & & \\
\hline
\end{tabular}


TABLE II. PRE-TEST DATA FOR THE NUMBER OF CORRECT ORDERS RECOGNIZED INDICATOR

\begin{tabular}{|c|c|c|c|c|c|}
\hline $\begin{array}{c}\text { Measure } \\
\text { ment }\end{array}$ & Attempts & $\begin{array}{c}\text { Total } \\
\text { Attempts }\end{array}$ & $\begin{array}{l}\text { C } \\
\text { O }\end{array}$ & $\begin{array}{l}\text { Visual } \\
\text { Orders }\end{array}$ & $\begin{array}{c}\text { Correct } \\
\text { Visual } \\
\text { Commands } \\
(\%) \\
\end{array}$ \\
\hline \multirow{2}{*}{ Person 1} & $\begin{array}{c}\text { Attempts } \\
\text { left }\end{array}$ & 6 & 2 & 0.3 & $30 \%$ \\
\hline & $\begin{array}{l}\text { Attempts } \\
\text { right }\end{array}$ & 4 & 1 & 0.3 & $30 \%$ \\
\hline \multirow{2}{*}{ Person 2} & $\begin{array}{c}\text { Attempts } \\
\text { left }\end{array}$ & 6 & 3 & 0.5 & $50 \%$ \\
\hline & $\begin{array}{l}\text { Attempts } \\
\text { right }\end{array}$ & 7 & 2 & 0.3 & $30 \%$ \\
\hline \multirow{2}{*}{ Person 3} & $\begin{array}{c}\text { Attempts } \\
\text { left }\end{array}$ & 6 & 5 & 0.8 & $80 \%$ \\
\hline & $\begin{array}{l}\text { Attempts } \\
\text { right }\end{array}$ & 4 & 1 & 0.3 & $30 \%$ \\
\hline \multirow{2}{*}{ Person 4} & $\begin{array}{c}\text { Attempts } \\
\text { left }\end{array}$ & 7 & 2 & 0.3 & $30 \%$ \\
\hline & $\begin{array}{l}\text { Attempts } \\
\text { right }\end{array}$ & 7 & 3 & 0.4 & $40 \%$ \\
\hline \multirow[b]{2}{*}{ Person 5} & $\begin{array}{l}\text { Attempts } \\
\text { left }\end{array}$ & 8 & 3 & 0.4 & $40 \%$ \\
\hline & $\begin{array}{c}\text { Attempts } \\
\text { right }\end{array}$ & 6 & 3 & 0.5 & $50 \%$ \\
\hline \multirow{2}{*}{ Person 6} & $\begin{array}{c}\text { Attempts } \\
\text { left }\end{array}$ & 7 & 4 & 0.6 & $60 \%$ \\
\hline & $\begin{array}{l}\text { Attempts } \\
\text { right }\end{array}$ & 4 & 0 & 0.0 & $0 \%$ \\
\hline \multirow{2}{*}{ Person 7} & $\begin{array}{l}\text { Attempts } \\
\text { left }\end{array}$ & 7 & 2 & 0.3 & $30 \%$ \\
\hline & $\begin{array}{l}\text { Attempts } \\
\text { right }\end{array}$ & 4 & 0 & 0.0 & $0 \%$ \\
\hline \multirow{2}{*}{ Person 8} & $\begin{array}{l}\text { Attempts } \\
\text { left }\end{array}$ & 7 & 0 & 0.0 & $0 \%$ \\
\hline & $\begin{array}{l}\text { Attempts } \\
\text { right }\end{array}$ & 8 & 3 & 0.4 & $40 \%$ \\
\hline \multirow{2}{*}{ Person 9} & $\begin{array}{l}\text { Attempts } \\
\text { left }\end{array}$ & 8 & 2 & 0.3 & $30 \%$ \\
\hline & $\begin{array}{l}\text { Attempts } \\
\text { right }\end{array}$ & 4 & 0 & 0.0 & $0 \%$ \\
\hline \multirow{2}{*}{ Person 10} & $\begin{array}{c}\text { Attempts } \\
\text { left }\end{array}$ & 4 & 0 & 0.0 & $0 \%$ \\
\hline & $\begin{array}{l}\text { Attempts } \\
\text { right }\end{array}$ & 6 & 2 & 0.3 & $30 \%$ \\
\hline \multicolumn{2}{|c|}{ TOTAL(OTR) } & 120 & 38 & & \\
\hline
\end{tabular}

2) Development of the intelligent software methodology

This section describes the phases to develop a visual command generator system, using computer vision and digital image processing with Python software and Arduino hardware making use of algorithms and functions from the OpenCV library. This research project is developed under the cascading life cycle [17], through the following stages:

a) Analysis: To identify the visual commands, an analysis of pupil movement was performed, using digital image processing to locate the eyes on the face and fix a pupil position within the central position of the eye, as well as to generate visual commands.

b) Design: In this phase the methods and techniques are determined in the different phases of image processing for the generation of visual orders.

3) Scene capture: An 18 Megapixel camera was used to capture the scene. The process is shown in Fig. 1.

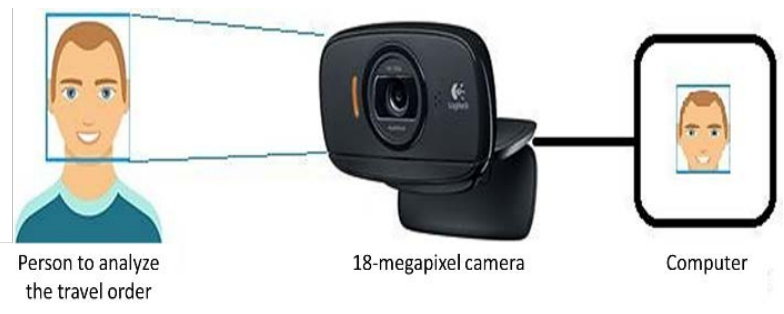

Fig. 1. Process of Capturing the Scene of the Face.

- Interface for software operation: Interface shows the capture of the scene by the camera, to process the image, to find the face, the eye and the pupil. Fig. 2 shows the precise moment when the command is given to the left side. Note that the left side is with respect to the screen, but not to the person.

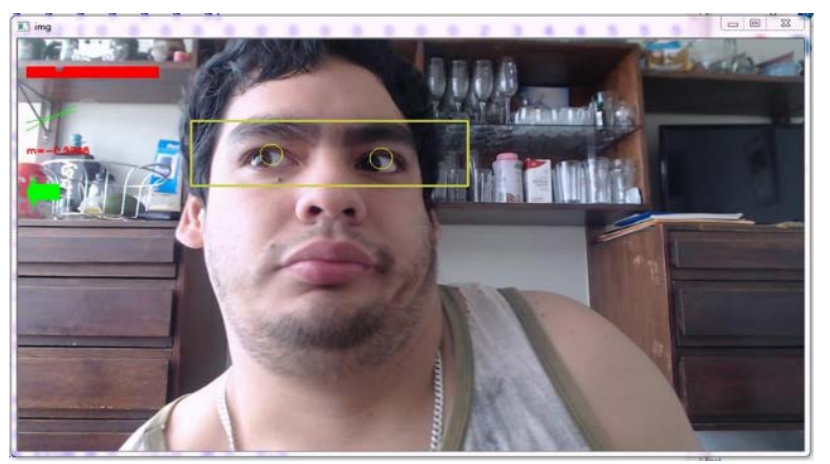

Fig. 2. Scene Interface as it Generates Visual Order.

- Fig. 3 shows the diagram of the hardware device made for this project.

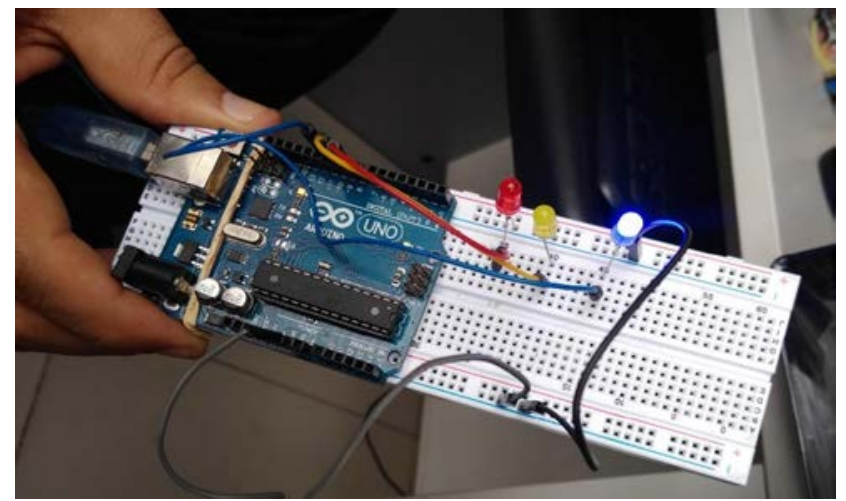

Fig. 3. Arduino Hardware Developed for the Project.

4) Processing: A flow chart was made to explain the process to send an order captured by the camera. (see Fig. 4)

5) Segmentation: It allows to highlight the scene in gray tone, necessary to be able to analyze the position of the pupil, in Fig. 6, it can be seen at the end of the process as the RGB graph changed to gray tone. The following Python source code was used for this purpose:

gray $=$ cv2.cvtColor (img, cv2.COLOR_BGR2GRAY) 


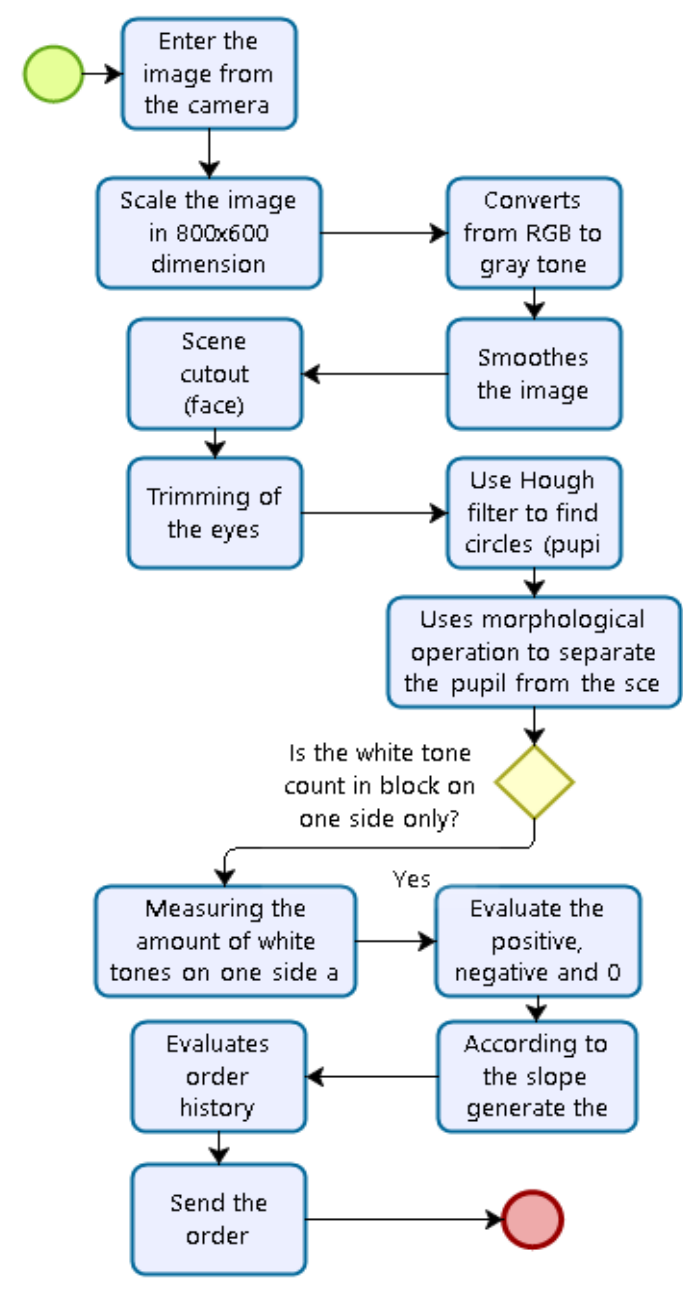

Fig. 4. Flow Chart of the Order Generation Process.

6) Description: Feature extraction technique. This is necessary to identify which is the necessary technique for the extraction of particular characteristics in a scene, and by means of it to locate the object in question helping to make a decision, for it is supported by the hough model and thus to be able to find the pupil.

First the image was obtained in gray tone, then the search was performed by the circular shape of the pupil (Hough filter) for this a morphological operation was used to extract the pupil from the environment, the amount of white tones at the ends of the pupil was counted. Finally, a slope line was generated to give order $(+,-, 0)=(\mathrm{d}, \mathrm{i}, \mathrm{e})$, this process is shown graphically in Fig. 10 and 11.

7) Visual order recognition: For the identification of movement orders (see process in Fig. 5), the number of pixels obtained as a gray tone (previously binarized) must be taken into account, therefore, it can be counted by means of the number of gray tones 1 (or 255) and 0 (or 0), for each column of the image, which in turn can be represented by the statistical method of dispersion, finding the line that represents that set of statistical values and thus finding the slope of that line created.

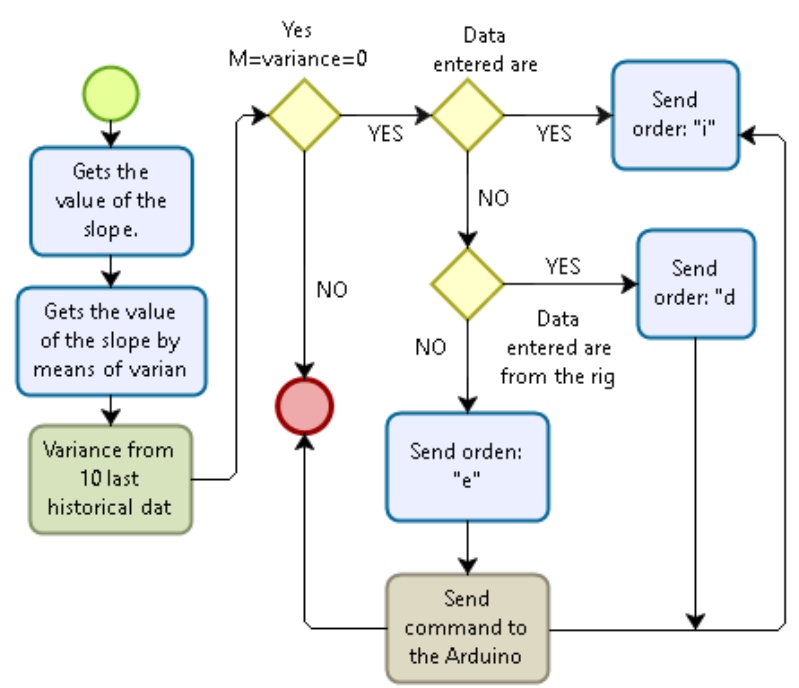

Fig. 5. Diagram of Visual Order Identification.

Considering the values of the orders of the slopes generated by the line of the white shades, to consider an order it is necessary to have a statistic of them.

- Order classification using digital image processing: To recognize the visual order it is necessary to consider the amount of gray tone data that are blank in order to identify them, then use the variance method for the amount of orders.

$S_{X}^{2}=\frac{\sum_{i=1}^{N}\left(X_{i}-\bar{x}\right)^{2}}{N-1}$

Being $\mathrm{X} 1, \mathrm{X} 2, \ldots, \mathrm{Xn}$, the set of $\mathrm{N}$ data, and $\mathrm{x}$ is the mean of these data. It is analyzed if $S$ is 0 , therefore, there is no variance, this implies that there is an intention to give an order, but if the data are different from 0 it implies that it has different types of orders, therefore, it does not generate an established order; this may be because it is looking at one side and then the other, etc.

Fig. 6 shows that the first step is to analyze whether there is a "Face" in the scene, for this it is necessary to locate and cut the scene in its position and size. Then it is necessary to reduce the scene to locate the eyes and detect the order that is performing, we proceed to the segmentation of the face, from the middle of the face upwards. In the third step of the process, the eyes are extracted in their position and size. Then the cut is made to perform the analysis. Finally, the pupil is identified to see its position and size, then it is changed to gray tone and the order is processed.

8) Implementation: For the implementation of the system based on digital image processing for the generation of visual orders, the following was considered:

a) Applied Technologies: Python 3.7.5 and OpenCV

b) Tests: The tests have been performed by means of the black box to measure the results of the application, detailing below with an example of test performed specified in Fig. 10 and 11. 


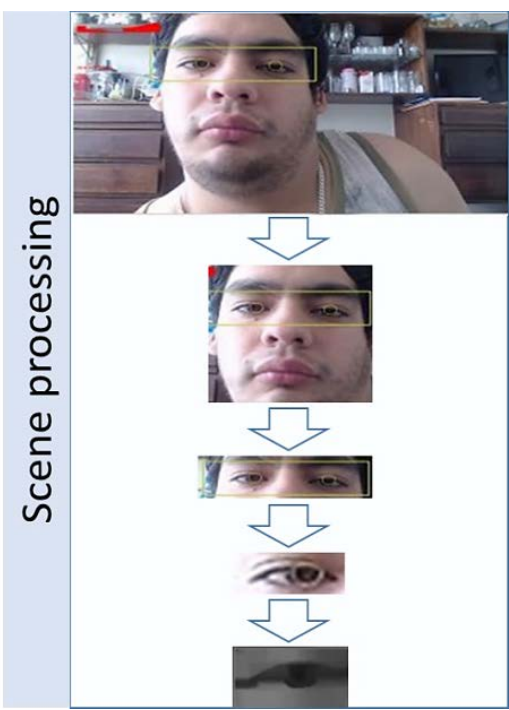

Fig. 6. Architecture for the Identification of the Visual Order.

Fig. 7, 8 and 9 detail the process for obtaining the evidence after the order is sent.

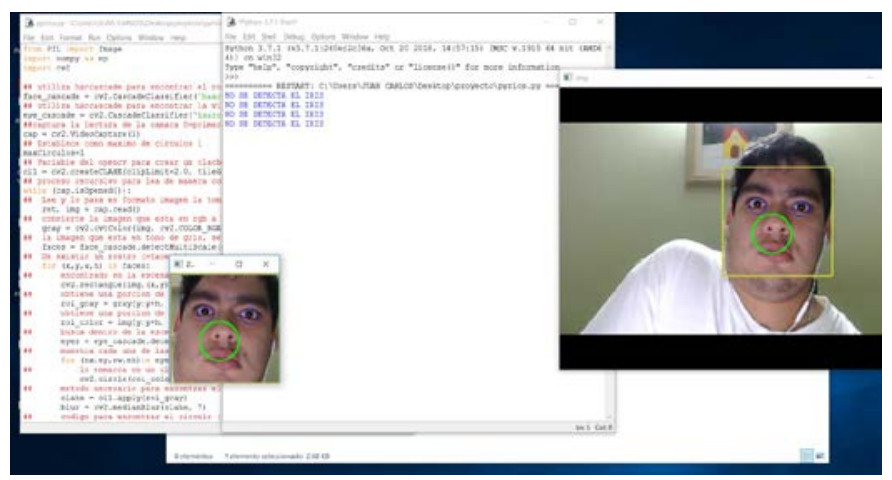

Fig. 7. Capturing the Scene of the Face - Initial Part.

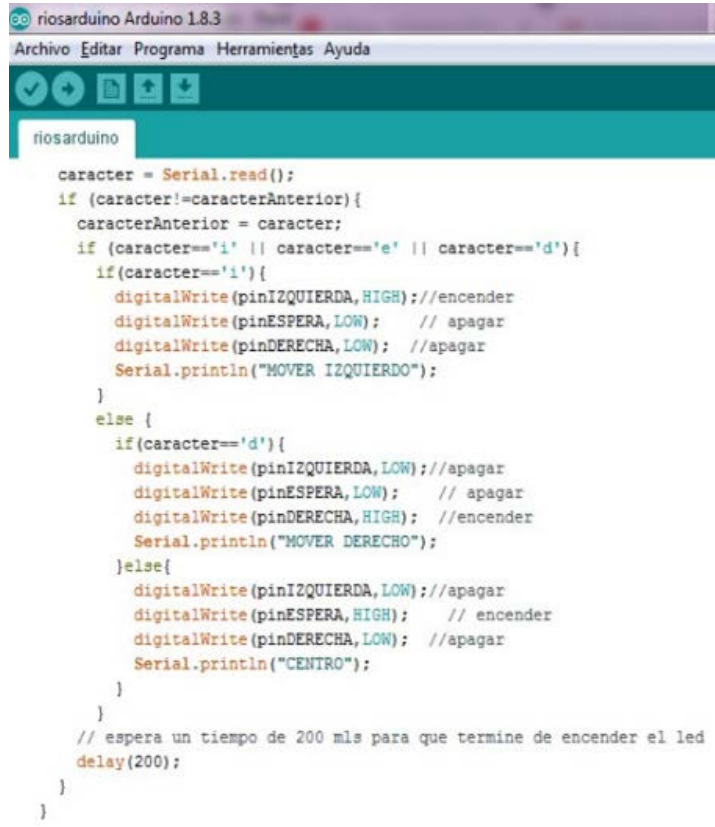

Fig. 8. Switching on the LED in Order.
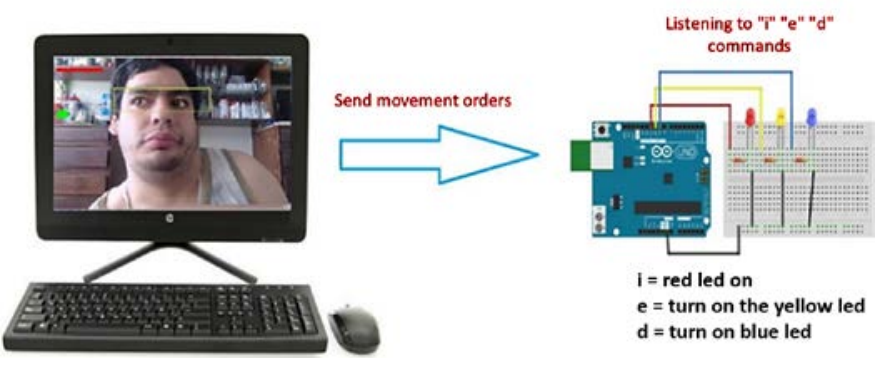

Fig. 9. Listening to Orders.

- Case assessed to person 1 :

TABLE III. EVALUATION OF THE GENERATION OF LEFT-HAND MOVEMENTS

\begin{tabular}{|l|l|l|}
\hline Measurement & Attempts made & Correct action \\
\hline Person 1 & Attempt left & Attempt left \\
\hline
\end{tabular}

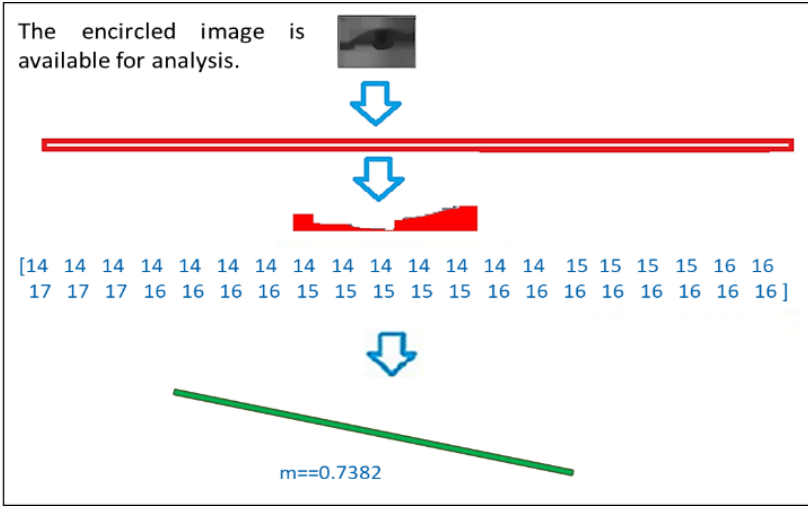

Fig. 10. Result Obtained by Performing the Test to Generate Visual Order to the Left.

- Case assessed to person 2:

TABLE IV. EVALUATION OF THE GENERATION OF RIGHT-HAND MOVEMENTS

\begin{tabular}{|l|l|l|}
\hline Measurement & Attempts made & Correct action \\
\hline Person 2 & Attempt right & Attempt right \\
\hline
\end{tabular}

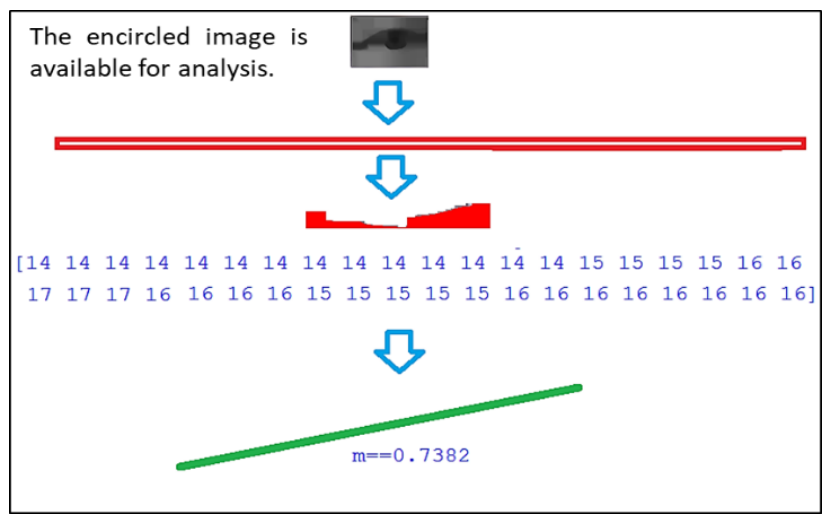

Fig. 11. Result obtained by Performing the Test of Generating Visual Order to the Right. 
Regarding the slope (m), its inclination is evaluated, and for the different experiments it is considered that the value of -0.2 or less indicates that it will perform the order to go to the right, values greater than 0.1 indicate that it will perform orders to the left, for any other case, it indicates that it will not perform any order.

9) Data collection after using the intelligent software:

a) Indicator 1: Index of recognition of travel orders. Data collection after using the intelligent software for the indicator travel order recognition index specified in Table V.

TABLE V. POST-TEST DATA FOR THE TRAVEL ORDER RECOGNITION INDEX INDICATOR

\begin{tabular}{|c|c|c|c|c|c|}
\hline $\begin{array}{l}\text { Test } \\
\text { case }\end{array}$ & Attempts & $\begin{array}{l}\text { Total } \\
\text { Attempts }\end{array}$ & CGCO & $\begin{array}{l}\text { Recognition } \\
\text { Rate }\end{array}$ & $\begin{array}{l}\text { Recognition } \\
\text { Rate (\%) }\end{array}$ \\
\hline \multirow{2}{*}{$\begin{array}{l}\text { Person } \\
1\end{array}$} & $\begin{array}{l}\text { Attempts } \\
\text { left }\end{array}$ & 10 & 9 & 0.9 & $90 \%$ \\
\hline & $\begin{array}{l}\text { Attempts } \\
\text { right }\end{array}$ & 10 & 8 & 0.8 & $80 \%$ \\
\hline \multirow[t]{2}{*}{$\begin{array}{l}\text { Person } \\
2\end{array}$} & $\begin{array}{l}\text { Attempts } \\
\text { left }\end{array}$ & 10 & 9 & 0.9 & $90 \%$ \\
\hline & $\begin{array}{l}\text { Attempts } \\
\text { right }\end{array}$ & 10 & 9 & 0.9 & $90 \%$ \\
\hline \multirow{2}{*}{$\begin{array}{l}\text { Person } \\
3\end{array}$} & $\begin{array}{l}\text { Attempts } \\
\text { left }\end{array}$ & 10 & 9 & 0.9 & $90 \%$ \\
\hline & $\begin{array}{l}\text { Attempts } \\
\text { right }\end{array}$ & 10 & 8 & 0.8 & $80 \%$ \\
\hline \multirow[b]{2}{*}{$\begin{array}{l}\text { Person } \\
4\end{array}$} & $\begin{array}{l}\text { Attempts } \\
\text { left }\end{array}$ & 10 & 9 & 0.9 & $90 \%$ \\
\hline & $\begin{array}{l}\text { Attempts } \\
\text { right }\end{array}$ & 10 & 8 & 0.8 & $80 \%$ \\
\hline \multirow[b]{2}{*}{$\begin{array}{l}\text { Person } \\
5\end{array}$} & $\begin{array}{l}\text { Attempts } \\
\text { left }\end{array}$ & 10 & 10 & 1 & $100 \%$ \\
\hline & $\begin{array}{l}\text { Attempts } \\
\text { right }\end{array}$ & 10 & 8 & 0.8 & $80 \%$ \\
\hline \multirow[b]{2}{*}{$\begin{array}{l}\text { Person } \\
6\end{array}$} & $\begin{array}{l}\text { Attempts } \\
\text { left }\end{array}$ & 10 & 8 & 0.8 & $80 \%$ \\
\hline & $\begin{array}{l}\text { Attempts } \\
\text { right }\end{array}$ & 10 & 6 & 0.6 & $60 \%$ \\
\hline \multirow[b]{2}{*}{$\begin{array}{l}\text { Person } \\
7\end{array}$} & $\begin{array}{l}\text { Attempts } \\
\text { left }\end{array}$ & 10 & 8 & 0.8 & $80 \%$ \\
\hline & $\begin{array}{l}\text { Attempts } \\
\text { right }\end{array}$ & 10 & 6 & 0.6 & $60 \%$ \\
\hline \multirow{2}{*}{$\begin{array}{l}\text { Person } \\
8\end{array}$} & $\begin{array}{l}\text { Attempts } \\
\text { left }\end{array}$ & 10 & 8 & 0.8 & $80 \%$ \\
\hline & $\begin{array}{l}\text { Attempts } \\
\text { right }\end{array}$ & 10 & 10 & 1 & $100 \%$ \\
\hline \multirow[b]{2}{*}{$\begin{array}{l}\text { Person } \\
9\end{array}$} & $\begin{array}{l}\text { Attempts } \\
\text { left }\end{array}$ & 10 & 10 & 1 & $100 \%$ \\
\hline & $\begin{array}{l}\text { Attempts } \\
\text { right }\end{array}$ & 10 & 8 & 0.8 & $80 \%$ \\
\hline \multirow{2}{*}{$\begin{array}{l}\text { Person } \\
10\end{array}$} & $\begin{array}{l}\text { Attempts } \\
\text { left }\end{array}$ & 10 & 9 & 0.9 & $90 \%$ \\
\hline & $\begin{array}{l}\text { Attempts } \\
\text { right }\end{array}$ & 10 & 9 & 0.9 & $90 \%$ \\
\hline \multicolumn{2}{|c|}{ TOTAL(TO) } & 200 & 169 & & \\
\hline
\end{tabular}

b) Indicator 2: Orders placed correctly. Data collection after using the intelligent software for the indicator of correct orders placed specified in Table VI.

Finally, calculations were made based on the formulas of the indicators.

- For indicator: Travel Order Recognition Rate

$I R O=\frac{C G C O}{T O} \times 100=\frac{169}{200}=0.85$

IRO: Index of Recognition of Travel Orders

CGCO: Correctly Generated Visual Commands.

TO: Total orders

- For the indicator: Correct visual orders carried out.

$C V C=\frac{C O}{T O P}=\frac{145}{169}=0.85$

CVC: Correct visual orders.

TABLE VI. POST-TEST DATA FOR CORRECT VISUAL ORDERS INDICATOR

\begin{tabular}{|c|c|c|c|c|c|}
\hline $\begin{array}{l}\text { Test } \\
\text { case }\end{array}$ & Attempts & $\begin{array}{l}\text { Total } \\
\text { Attempts }\end{array}$ & CGCO & $\begin{array}{l}\text { Recognition } \\
\text { Rate }\end{array}$ & $\begin{array}{l}\text { Recognition } \\
\text { Rate (\%) }\end{array}$ \\
\hline \multirow{2}{*}{ Person 1} & $\begin{array}{l}\text { Attempts } \\
\text { left }\end{array}$ & 9 & 8 & 0.9 & $90 \%$ \\
\hline & $\begin{array}{l}\text { Attempts } \\
\text { right }\end{array}$ & 8 & 8 & 1.0 & $100 \%$ \\
\hline \multirow{2}{*}{ Person 2} & $\begin{array}{l}\text { Attempts } \\
\text { left }\end{array}$ & 9 & 8 & 0.9 & $90 \%$ \\
\hline & $\begin{array}{l}\text { Attempts } \\
\text { right }\end{array}$ & 9 & 5 & 0.6 & $60 \%$ \\
\hline \multirow{2}{*}{ Person 3} & $\begin{array}{l}\text { Attempts } \\
\text { left }\end{array}$ & 9 & 9 & 1.0 & $100 \%$ \\
\hline & $\begin{array}{l}\text { Attempts } \\
\text { right }\end{array}$ & 8 & 6 & 0.8 & $80 \%$ \\
\hline \multirow[b]{2}{*}{ Person 4} & $\begin{array}{l}\text { Attempts } \\
\text { left }\end{array}$ & 9 & 8 & 0.9 & $90 \%$ \\
\hline & $\begin{array}{l}\text { Attempts } \\
\text { right }\end{array}$ & 8 & 6 & 0.8 & $80 \%$ \\
\hline \multirow[b]{2}{*}{ Person 5} & $\begin{array}{l}\text { Attempts } \\
\text { left }\end{array}$ & 10 & 9 & 0.9 & $90 \%$ \\
\hline & $\begin{array}{l}\text { Attempts } \\
\text { right }\end{array}$ & 8 & 6 & 0.8 & $80 \%$ \\
\hline \multirow[b]{2}{*}{ Person 6} & $\begin{array}{l}\text { Attempts } \\
\text { left }\end{array}$ & 8 & 8 & 1.0 & $100 \%$ \\
\hline & $\begin{array}{l}\text { Attempts } \\
\text { right }\end{array}$ & 6 & 4 & 0.7 & $70 \%$ \\
\hline \multirow[b]{2}{*}{ Person 7} & $\begin{array}{l}\text { Attempts } \\
\text { left }\end{array}$ & 8 & 8 & 1.0 & $100 \%$ \\
\hline & $\begin{array}{l}\text { Attempts } \\
\text { right }\end{array}$ & 6 & 5 & 0.8 & $80 \%$ \\
\hline \multirow[b]{2}{*}{ Person 8} & $\begin{array}{l}\text { Attempts } \\
\text { left }\end{array}$ & 8 & 8 & 1.0 & $100 \%$ \\
\hline & $\begin{array}{l}\text { Attempts } \\
\text { right }\end{array}$ & 10 & 8 & 0.8 & $80 \%$ \\
\hline \multirow[b]{2}{*}{ Person 9} & $\begin{array}{l}\text { Attempts } \\
\text { left }\end{array}$ & 10 & 6 & 0.6 & $60 \%$ \\
\hline & $\begin{array}{l}\text { Attempts } \\
\text { right }\end{array}$ & 8 & 8 & 1.0 & $100 \%$ \\
\hline \multirow[b]{2}{*}{$\begin{array}{l}\text { Person } \\
10\end{array}$} & $\begin{array}{l}\text { Attempts } \\
\text { left }\end{array}$ & 9 & 8 & 0.9 & $90 \%$ \\
\hline & $\begin{array}{l}\text { Attempts } \\
\text { right }\end{array}$ & 9 & 9 & 1.0 & $100 \%$ \\
\hline \multicolumn{2}{|c|}{ TOTAL(TO) } & 169 & 145 & & \\
\hline
\end{tabular}


TOP: Total orders placed.

\section{CO: Correct Orders}

\section{RESUltS}

\section{A. Descriptive Analysis}

In the study, an intelligent software (Independent Variable) was applied to evaluate the order recognition index and the correct orders carried out for the displacement order (Dependent Variable); for this purpose, a Pre-Test was applied to know the initial conditions of the indicator; subsequently, the intelligent software was implemented and the order recognition index and the correct orders carried out for the displacement order were recorded again.

1) Order recognition index indicator: The descriptive results of the order recognition index. In the pre-test a value of $60.25 \%$ was obtained, while in the post-test it was $84.5 \%$ as shown in Fig. 14; this indicates a great difference before and after the implementation of the intelligent software (see Fig. 12).

Regarding the dispersion of the order recognition index, in the pre-test there was a variability of 0.15 ; however, in the post-test there was a value of 0.11 .

2) Indicator - Number of correct orders placed: The descriptive results of the number of correct realized orders. In the case of the number of correct orders to generate displacement orders, in the pre-test a value of $29 \%$ was obtained, while in the post-test it was $86 \%$ as shown in Fig. 15; this indicates a great difference before and after the implementation of the intelligent software (see Fig. 13).

Regarding the dispersion of the number of correct orders, in the pre-test there was a variability of 0.21 ; however, in the post-test there was a value of 0.13 .

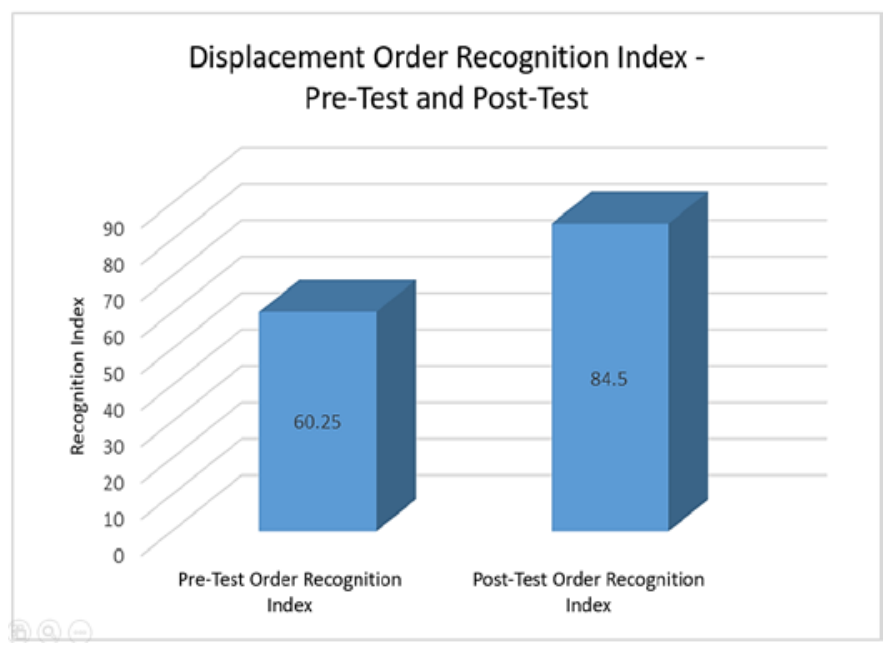

Fig. 12. Displacement Order Recognition Index - Pretest and Posttest.

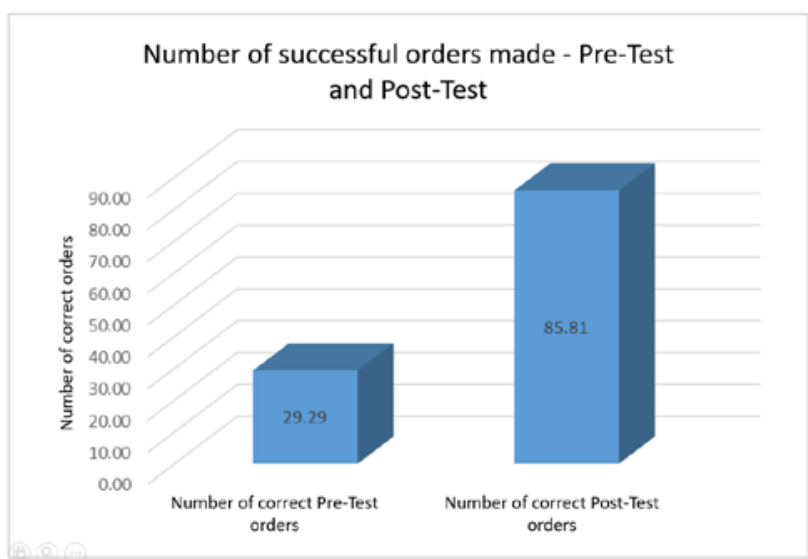

Fig. 13. Number of Correct Orders Placed, Pretest and Posttest.

\section{B. Order Recognition Index}

The order recognition index according to the data in Table V and Table III is shown in Fig. 14.

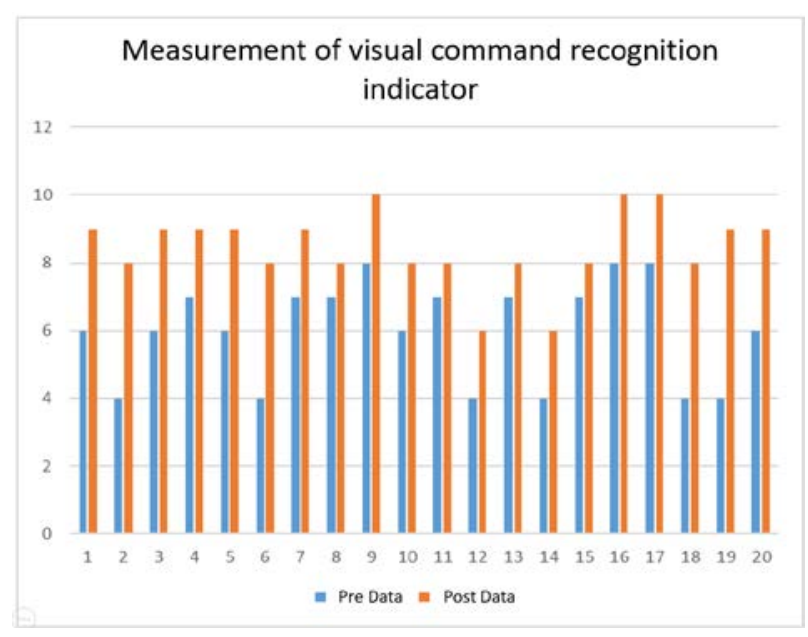

Fig. 14. Measurement of the Visual Command Recognition Indicator.

1) Indicator of correct visual orders: The number of orders recognized according to the data in Tables VI and IV is shown in Fig. 15.

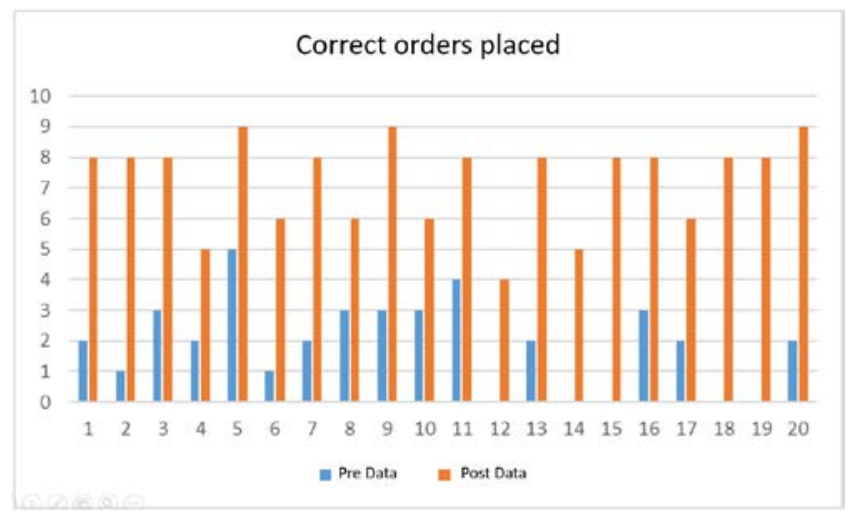

Fig. 15. Measurement of Order Recognition Rate. 


\section{Discussion AND CONCLUSION}

The influence of intelligent software on the intelligence degree dimension of visual command recognition for people with disabilities according to the visual command recognition rate of 169 correct recognitions out of 200; therefore, using the appropriate model and algorithms results in a visual command recognition rate of 0.85 . The influence of intelligent software on the visual order dimension of recognizing the correct orders was demonstrated for people with disabilities according to the rate of recognition of correct visual commands obtained in the tests, which were 145 correct recognitions out of 169; therefore, it is obtained with respect to the rate of generation of correct visual commands of 0.86 .

Based on the results obtained, we can infer that the solution can be applied to another person with a disability. Based on the results obtained, we can infer that the solution can be applied to another person with a disability. In addition, the intelligent software had a positive influence on the recognition of movement commands from movements.

This prototype serves as a basis for new knowledge concerning digital image processing and external devices such as sensors.

\section{RECOMMENDATIONS}

The present research can be used as a background to find the order recognition rate taking as a reference an effectiveness rate of 0.845 and a rate of correct orders placed of 0.858 plotted.

It is recommended to use a general model to be applied in software for anyone who wants to use it, regardless of whether they have a motor disability, as well as using devices such as Raspberry $\mathrm{Pi}$, to try to become independent with a portable hardware.

\section{REFERENCES}

[1] UN, "Disability and Development Report: Realizing the Sustainable Development Goals by, for and with persons with disabilities.," New York, United States of America, 2019. doi: 10.4337/9781847202864.00035.

[2] UN, "Disability and Development Report: Realizing the SDGs by, for and with persons with disabilities. Chapter 2.," New York, United States of America, 2019.

[3] Organización Mundial de la Salud and Banco Mundial, "Disability and
Development Report,” 2011. [Online]. Available: http://www.who.int/disabilities/world_report/2011/report/en/.

[4] INEI, "Perú: Características de la Población con Discapacidad,” Lima Peru, 2015. [Online]. Available: https://www.inei.gob.pe/.

[5] R. Li et al., "Automated fine motor evaluation for developmental coordination disorder,” IEEE Trans. Neural Syst. Rehabil. Eng., vol. 27, no. 5, pp. 963-973, 2019, doi: 10.1109/TNSRE.2019.2911303.

[6] M. Skarsgard, S. C. D. Dobri, D. Samdup, S. H. Scott, and T. C. Davies, "Toward Robot-Assisted Diagnosis of Developmental Coordination Disorder,” IEEE Robot. Autom. Lett., vol. 4, no. 2, pp. 346-350, 2019, doi: 10.1109/LRA.2018.2885197Y.

[7] K. J. Wang et al., "Brain-computer interface combining eye saccade two-electrode EEG signals and voice cues to improve the maneuverability of wheelchair," IEEE Int. Conf. Rehabil. Robot., pp. 1073-1078, 2017, doi: 10.1109/ICORR.2017.8009392.

[8] J. L. Collinger et al., "High-performance neuroprosthetic control by an individual with tetraplegia,” Lancet, vol. 381, no. 9866, pp. 557-564, 2013, doi: 10.1016/S0140-6736(12)61816-9.

[9] M. Tang, "Image Segmentation Technology and Its Application in Digital Image Processing," IEEE, 2020, doi: 10.1109/ICAACI50733.2020.00040.

[10] G. Quere et al., "Shared Control Templates for Assistive Robotics," Proc. - IEEE Int. Conf. Robot. Autom., pp. 1956-1962, 2020, doi: 10.1109/ICRA40945.2020.9197041.

[11] A. Broce, “ARQUITECTURAS COMPARTIDAS,” 2018. http://solca.innovacion.gob.pa/wp-content/uploads/2019/04/1ARQUITECTURAS-COMPARTIDAS.pdf (accessed Mar. 29, 2021).

[12] T. I. Chowdhury, "Towards Reverse Disability Simulation in a Virtual Environment," 25th IEEE Conf. Virtual Real. 3D User Interfaces, VR 2018 - Proc., pp. 803-804, 2018, doi: 10.1109/VR.2018.8446146.

[13] S. S. Khan, M. S. H. Sunny, M. S. Hossain, E. Hossain, and M. Ahmad, "Nose tracking cursor control for the people with disabilities: An improved HCI," 3rd Int. Conf. Electr. Inf. Commun. Technol. EICT 2017, vol. 2018-January, no. December, pp. 1-5, 2018, doi: 10.1109/EICT.2017.8275178.

[14] C. Manterola, G. Quiroz, P. Salazar, and N. García, "Metodología de los tipos y diseños de estudio más frecuentemente utilizados en investigación clínica,” Rev. Med. Clin. Condes, vol. 30, no. 1, pp. 3649, 2019, [Online]. Available: https://doi.org/10.1016/j.rmclc.2018.11.005.

[15] F. García, “Ingeniería en Software,” pp. 277-388, 2018, [Online]. Available: https://repositorio.grial.eu/bitstream/grial/1228/1/07-rep.pdf.

[16] C. Escudero and L. Cortez, "Técnicas y Métodos cualitativos para la ivestigación científica. Cap. 1,” in Técnicas y métodos cualitativos para la investigación científica., First edit., vol. 6, no. 11, Editorial UTMACH, 2018, pp. 951-952.

[17] I. SOMMERVILLE, "Ingenieria del Software 7ma. Ed. - Ian Sommerville.pdf.” p. 691, 2004. 